Transcontinentales

continentales

Sociétés, idéologies, système mondial

Afrique plurielle

\title{
Pays du Sud
}

\section{(2) OpenEdition \\ 12 Journals}

\section{Édition électronique}

URL : http://journals.openedition.org/transcontinentales/1497

DOI : $10.4000 /$ transcontinentales. 1497

ISBN : 978-2-8218-1408-0

ISSN : 1775-397X

\section{Éditeur}

Editions de la maison des sciences de l'homme

\section{Édition imprimée}

Date de publication : 30 juin 2006

Pagination : 188

ISBN : 2200-92169-1

ISSN : 1950-1684

\section{Référence électronique}

«Pays du Sud », Transcontinentales [En ligne], 2 | 2006, document 32, mis en ligne le 15 décembre

2012, consulté le 25 septembre 2020. URL : http://journals.openedition.org/transcontinentales/1497 ; DOI : https://doi.org/10.4000/transcontinentales.1497

Ce document a été généré automatiquement le 25 septembre 2020.

Tous droits réservés 


\section{Pays du Sud}

DESGRÉES DU LOÛ Annabel et Benoît FERRY (éds), Sexualité et procréation confrontées au Sida dans les pays du Sud, Paris, CEPED, 2006, 273 p. 